ARTICLE

\title{
Efficient backbone cyclization of linear peptides by a recombinant asparaginyl endopeptidase
}

Karen S. Harris ${ }^{1, \star}$, Thomas Durek ${ }^{2, \star}$, Quentin Kaas ${ }^{2}$, Aaron G. Poth ${ }^{2}$, Edward K. Gilding ${ }^{2}$, Brendon F. Conlan ${ }^{1, \dagger}$, Ivana Saska ${ }^{2}$, Norelle L. Daly ${ }^{2, \dagger}$, Nicole L. van der Weerden ${ }^{1}$, David J. Craik ${ }^{2} \&$ Marilyn A. Anderson ${ }^{1}$

Cyclotides are diverse plant backbone cyclized peptides that have attracted interest as pharmaceutical scaffolds, but fundamentals of their biosynthetic origin remain elusive. Backbone cyclization is a key enzyme-mediated step of cyclotide biosynthesis and confers a measure of stability on the resultant cyclotide. Furthermore, cyclization would be desirable for engineered peptides. Here we report the identification of four asparaginyl endopeptidases (AEPs), proteases implicated in cyclization, from the cyclotide-producing plant Oldenlandia affinis. We recombinantly express $\mathrm{OaAEP} 1_{b}$ and find it functions preferably as a cyclase by coupling C-terminal cleavage of propeptide substrates with backbone cyclization. Interestingly, $\mathrm{OaAEP}_{\mathrm{b}}$ cannot cleave at the $\mathrm{N}$-terminal site of $\mathrm{O}$. affinis cyclotide precursors, implicating additional proteases in cyclotide biosynthesis. Finally, we demonstrate the broad utility of this enzyme by cyclization of peptides unrelated to cyclotides. We propose that recombinant $\mathrm{OaAEP1}_{\mathrm{b}}$ is a powerful tool for use in peptide engineering applications where increased stability of peptide products is desired.

\footnotetext{
${ }^{1}$ Department of Biochemistry and Genetics, La Trobe Institute for Molecular Science, La Trobe University, Melbourne, Victoria 3086, Australia. ${ }^{2}$ Division of Chemistry and Structural Biology, Institute for Molecular Bioscience, The University of Queensland, Brisbane, Queensland 4072, Australia. * These authors contributed equally to this work. †Present addresses: Research School of Biology, Australian National University, Canberra, Australian Capital Territory 0200, Australia (B.F.C.); Centre for Biodiscovery and Molecular Development of Therapeutics, AITHM, James Cook University, Cairns, Queensland 4878, Australia (N.L.D.). Correspondence and requests for materials should be addressed to M.A. (email: m.anderson@latrobe.edu.au)
} 
P roteases are abundant throughout nature and are essential for a wide range of cellular processes. They typically serve to hydrolyse polypeptide chains, resulting in either degradation of the target sequence or maturation to a biologically active form. Less frequently, proteases can also ligate polypeptides, producing new or alternatively spliced variants. This unusual function has been reported for processes such as the maturation of the lectin concanavalin $\mathrm{A}^{1}$, peptide presentation by major histocompatibility complex class I molecules ${ }^{2}$, and anchoring of bacterial proteins to the cell wall ${ }^{3}$. Recently, this enzymatic transpeptidation has also been implicated in the backbone cyclization of ribosomally synthesized cyclic peptides ${ }^{4-10}$.

Cyclotides are a well-studied class of gene-encoded cyclic peptides that are expressed in plants and exhibit a range of bioactivities including insecticidal, nematicidal and molluscicidal activity against agricultural pests ${ }^{11-14}$. Structurally, they are characterized by a cyclic cystine knot motif that confers exceptional stability. Importantly, this stable framework can be used as a pharmaceutical scaffold, and bioactive sequences have been successfully grafted into cyclotides ${ }^{15}$. Backbone cyclization can also endow peptides with oral bioavailability, suggesting that this modification might find broad application in peptide drug engineering $^{16-18}$. However, in vitro cyclization of synthetic peptides is challenging and the limited availability of enzymes capable of this process is a hurdle to large-scale production ${ }^{19,20}$. Furthermore, expression yields of cyclotides in transgenic plants that are not native cyclotide producers is poor, impeding transfer of agriculturally relevant bioactivities to other plants ${ }^{8,21}$. The mechanism of enzymatic cyclization intrinsic to cyclotide biosynthesis is poorly understood. Elucidating it will be important for the realization of the pharmaceutical and agricultural potential of cyclotides and for increasing the cyclization efficiency of unrelated 'designed' bioactive peptides.

Cyclotides are produced as precursors in which the cyclotide sequence is flanked by $\mathrm{N}$ - and C-terminal propeptides (Fig. 1). It is thought that enzymatic removal of the $\mathrm{N}$-terminal propeptide precedes the final maturation step of C-terminal propeptide cleavage and ligation of the free $\mathrm{N}$ - and C-termini ${ }^{8,21}$. Only four native cyclases have been identified to date and the best characterized of these is the serine protease PatG, which cyclizes the bacterial cyanobactins ${ }^{4-7}$. In plants, the serine protease PCY1 cyclizes the segetalins; cyclic peptides from the Caryophyllaceae ${ }^{4}$. However, in the two other classes of plant-derived cyclic peptides (cyclotides and the PawS-derived cyclic peptides), strong Asx sequence conservation at the C-terminal P1 site implicates as possible cyclases the asparaginyl endopeptidases (AEPs), a group of cysteine proteases also known as vacuolar processing enzymes or Legumains, and this hypothesis is supported by studies in transgenic plants $8,9,21,22$.

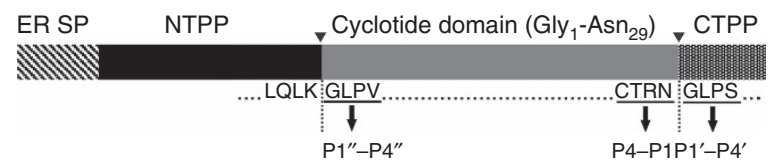

Figure 1 | Schematic representation of the Oak1 gene. The precursor protein encoded by the Oak1 gene is proteolytically processed to mature kB1. $\boldsymbol{\nabla}$ indicates the $\mathrm{N}$ - and $\mathrm{C}$-terminal processing sites. $\mathrm{rOaAEP} 1_{\mathrm{b}}$ targets the $\mathrm{C}$-terminal processing site. The $\mathrm{C}$-terminal $\mathrm{P} 1 / \mathrm{P}^{\prime}$ - $\mathrm{P} 4 / \mathrm{P}^{\prime}$ sites are indicated. $\mathrm{P}^{\prime \prime}-\mathrm{P} 4^{\prime \prime}$ denote the $\mathrm{N}$-terminal residues that replace the $\mathrm{P}^{\prime}-\mathrm{P} 4^{\prime}$ residues on release of the $\mathrm{C}$-terminal propeptide. CTPP, C-terminal propeptide; ER SP, endoplasmic reticulum signal peptide; NTPP, N-terminal propeptide.
Recently, an AEP (butelase 1) was isolated from the cyclotideproducing plant Clitoria ternatea and shown to cyclize a modified precursor of the prototypical cyclotide, kalata B1 (kB1) from Oldenlandia affinis, however, recombinant expression of functionally active butelase 1 has not been achieved, limiting its application ${ }^{5}$. Only one AEP with any cyclizing ability has been produced recombinantly, and this enzyme was highly inefficient, producing mainly hydrolysed substrate ${ }^{10}$. Here we report the identification, recombinant production and characterization of an $O$. affinis AEP that preferentially functions as a cyclase. The enzyme can cyclize native kalata substrate precursors and the unrelated anti-malarial peptide, R1, at close to $100 \%$ efficiency. This AEP releases the C-terminal propeptide of $\mathrm{kB1}$, but it does not mediate the $\mathrm{N}$-terminal processing event, which must occur first if efficient cyclization is to take place. Moreover, its specificity for model peptides mirrors the sequence requirements for cyclization of $\mathrm{kB1}$ in transgenic plants, supporting a native function in the maturation of $O$. affinis cyclotides $^{8,21}$.

\section{Results}

Identification and recombinant expression of $O$. affinis AEPs. Three expressed AEP isoforms were identified in an O. affinis complementary DNA library (OaAEP1-3) and a fourth sequence, with a single nucleotide change from OaAEP1 (resulting in a $\mathrm{Glu}_{371} \mathrm{Val}$ variant), was identified from genomic DNA $\left(O a \mathrm{AEP}_{\mathrm{b}}\right)$ (Fig. 2a; Supplementary Fig. 1). The four isoforms share at least $77 \%$ identity at the protein level, as determined by pairwise protein alignments. When compared with butelase 1 , 64-69\% identity was observed, whereas identity with human legumain was $49-53 \%$.

OaAEP1 $1_{\mathrm{b}}$ was expressed in Escherichia coli as a His6-ubiquitin$A E P 1_{b}$ fusion protein (Supplementary Fig. 2a). AEPs are usually produced as zymogens that are self-processed at low $\mathrm{pH}$ to their mature, active form ${ }^{23-25}$. Consistent with this processing, activity of $\mathrm{rOaAEP} 1_{\mathrm{b}}$ against an internally quenched fluorescent (IQF) peptide representing the native $\mathrm{C}$-terminal processing site in $\mathrm{kB1}$ (Table 1; wildtype (wt)) was markedly increased following incubation at $\mathrm{pH} 4.5$ (Fig. 2b). After purification, a dominant band of $\sim 32 \mathrm{kDa}$ was evident by reducing SDS-polyacrylamide gel electrophoresis (PAGE) and confirmed to be $\mathrm{rOaAEP} 1_{\mathrm{b}}$ by Western blotting (Fig. 2c; Supplementary Fig. 2b). The average total protein yield from two independent experiments was $\sim 1.8 \mathrm{mgl}^{-1}$ after activation and purification, however batch to batch variation in purity was observed. Although glycosylation of some AEPs has been reported ${ }^{26}$, the production of an active form in $E$. coli confirms that this is not a requirement for activity of O. affinis $\mathrm{AEP} 1_{\mathrm{b}}$.

Mass spectrometry (MS)/MS sequencing of peptide fragments generated from tryptic, chymotryptic or endoGlu-C digestion of the activated enzyme identified several peptide fragments with noncanonical cleavage sites, suggesting that they may be derived from $\mathrm{rOaAEP} 1_{\mathrm{b}}$ auto-processing events (Supplementary Fig. 2). This allowed Asp52 to be assigned as the likely N-terminal autoprocessing site and Asp328, Asn329, Asp334, Asn336, Asp349 and/ or Asp351 as potential C-terminal processing sites (Fig. 2a; Supplementary Fig. 2). No peptides downstream of Asp351 were identified, indicating that the activation was essentially complete and that the C-terminal domain (Leu352-Pro474) was removed during the post-activation purification step. The theoretical mass of the processed forms $(30.4-32.8 \mathrm{kDa})$ is in good agreement with that determined by SDS-PAGE/Western blotting (Fig. 2c).

Consistent with cysteine proteases of this class, $\mathrm{rOaAEP} 1_{\mathrm{b}}$ was inhibited by iodoacetamide $(1 \mathrm{mM})$, but was not affected by E64 $(250 \mu \mathrm{M})$ or pepstatin A $(10 \mu \mathrm{M})$ (Supplementary Fig. 3). Ac-YVAD-CHO $(500 \mu \mathrm{M})$, a caspase-1 inhibitor reported to also 
a

1- MVRYLAGAVL LLVVLSVAAA VSÅ̈ARDGDYL HLPSEVSRFF 41- RPQETNDDHG EDSVGTRWAV LIAGSKGYAN YRHQAGVCHA 81- YQILKRGGLK DENIVVFMYD DIAYNESNPR PGVIINSPHG 121- SDVYAGVPKD YTGEEVNAKN FLAAILGNKS AITGGSGKVV 161- DSGPNDHIFI YYTDHGAAGV IGMPSKPYLY ADELNDALKK 201- KHASGTYKSL VFYLEAC 241- TTESSWCYYC PAQENPPPPE YNVCLGDLFS VAWLEDSDVQ 281- NSWYETLNQQ YHHVDKRISH ASHATQYGNL KLGEEGLFVY 321- MGSNPANDNY TSLDGNALTP SSIVVNQRDA DLLHLWEKFR 361- KAPEGSARKE VAQTQIFKAM SHRVHIDSSI KLIGKLLFGI 401- EKCTEILNAV RPAGQPLVDD WACLRSLVGT FETHCGSLSE 441- YGMRHTRTIA NICNAGISEE QMAEAASOAC ASIP b

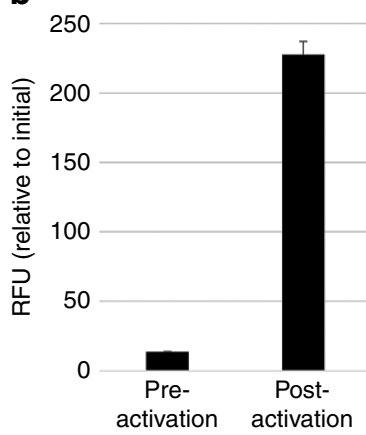

C

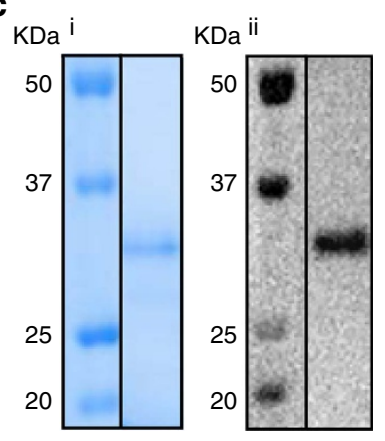

Figure 2 | Expression of active rOaAEP1 in E. coli. (a) Sequence of $O a A E P 1_{b}$ predicted from $O$. affinis genomic DNA. Predicted ER signal sequence shown in red; $\mathrm{N}$-terminal propeptide shown in blue; the putative signal peptidase cleavage site is indicated by $\nabla$ and autocatalytic processing sites by $\boldsymbol{\nabla}$. The mature OaAEP1 cyclase domain is underlined and the C-terminal auto-processing region is indicated with broken underline. The putative catalytic dyad is shown in bold and labelled with *. (b) An rOaAEP1-containing anion exchange fraction pre-and post-activation at $\mathrm{pH} 4.5\left(5 \mathrm{~h}, 37^{\circ} \mathrm{C}\right)$ was tested for activity against the wt IQF peptide $(14 \mu \mathrm{M})$. Baseline fluorescence from a no substrate control has been subtracted and the relative fluorescence intensity (RFU) at $t=90 \mathrm{~min}$ is reported. The average of two technical replicates is shown and error bars report the range (c) Activated $\mathrm{rOaAEP} 1_{\mathrm{b}}$ purified by cation exchange was analysed by SDS-PAGE and (i) Instant blue staining or (ii) Western blotting with anti-OaAEP1 (residues $\mathrm{D}_{47}-\mathrm{P}_{474}$ ) polyclonal rabbit serum. inhibit $\mathrm{AEPs}^{27}$, was a poor inhibitor of the recombinant enzyme suggesting that at least some $\mathrm{P}^{\prime}$ residues are important for active site targeting.

Substrate specificity. The activity of $\mathrm{rOaAEP} 1_{\mathrm{b}}$ against IQF peptides representing wt and mutant versions of the native $\mathrm{kB1}$ C-terminal cleavage site was determined (Table 1; Supplementary Fig. 4a). Along with the strict P1 Asx specificity characteristic of $\mathrm{AEPs}^{24}, \mathrm{rOaAEP}_{\mathrm{b}}$ exhibited strong $\mathrm{P} 2^{\prime}$ selectivity since after Leu $_{31}$ Ala substitution within the IQF peptide barely any hydrolysis was observed. This observation is consistent with the lack of cyclic product generated when the corresponding mutation was introduced in planta ${ }^{21}$. Kinetic parameters $\left(V_{\max }\right.$, $K_{\mathrm{m}}$ and $\left.k_{\text {cat }}\right)$ are reported where applicable (Table 1). The turnover rates $\left(k_{\text {cat }}\right)$ reported here $\left(\sim 0.06-1.6 \mathrm{~min}^{-1}\right)$ are much slower than that reported for recombinant human legumain assayed against a small substrate $\left(\sim 8 s^{-1}\right)$ (ref. 28 ). This is not unexpected given that $\mathrm{rOaAEP} 1_{\mathrm{b}}$ prefers to carry out cyclization, rather than the hydrolysis being measured here. Supporting the observed $\mathrm{P} 2$ ' selectivity, $\mathrm{rOaAEP} 1_{\mathrm{b}}$ was unable to cleave the generic AEP substrate Z-AAN-MCA (Supplementary Fig. 5).

The substrate specificity of $\mathrm{rOaAEP} 1_{\mathrm{b}}$ was compared with that of recombinant human legumain (rhuLEG; Supplementary Fig. 4b $)^{29}$. A stringent P1 Asx requirement was again observed; however, in contrast to $\mathrm{rOaAEP} 1_{\mathrm{b}}$, rhuLEG cleaved the $\mathrm{Leu}_{31} \mathrm{Ala}$ substrate at a rate similar to the wt substrate, demonstrating that $\mathrm{P} 2^{\prime}$ specificity is not a feature of all AEPs.

Cyclization of $\mathbf{k B 1}$ precursors. To explore the cyclization ability of $\mathrm{rOaAEP} 1_{\mathrm{b}}$, processing of correctly folded (as determined by NMR) synthetic $\mathrm{kB1}$ precursors was assessed by MS. When incubated with the wt $\mathrm{kB1}$ precursor carrying the native C-terminal pro-hepta-peptide (GLPSLAA), the active enzyme produced a peptide of $2,891.2 \mathrm{Da}$ (monoisotopic, $[\mathrm{M}+\mathrm{H}]^{+}$), consistent with the expected mass of mature, cyclic kB1 (Fig. 3a). This product was confirmed to be identical to native $\mathrm{kB1}$ by reversed phase-high performance liquid chromatography (RP-HPLC) co-elution (Supplementary Fig. 6) and one- and two-dimensional-NMR experiments (Supplementary Fig. 7). Kinetic parameters $( \pm$ s.e.m.) for the processing of the wt $\mathrm{kB1}$ precursor were $0.53( \pm 0.1) \mathrm{s}^{-1}$ for $k_{\text {cat }}, 212( \pm 76) \mu \mathrm{M}$ for $K_{\mathrm{m}}$ and $2,500 \mathrm{M}^{-1} \mathrm{~s}^{-1}$ for $k_{\mathrm{cat}} / K_{\mathrm{m}}$ as determined from a Michaelis-Menten plot (Supplementary Fig. 8). While the turnover rate $\left(k_{\text {cat }}\right)$ is lower than that reported for the plant-derived

Table 1 | Kinetic parameters of IQF peptide cleavage by YaVPE1 $_{b}$.

\begin{tabular}{|c|c|c|c|c|}
\hline IQF peptide & Sequence $^{\star}$ & $V_{\max }\left(\right.$ nmoles min $^{-1} \mathrm{mg}^{-1}$ protein $)( \pm \text { s.e.m. })^{\dagger}$ & $K_{m}(\mu M)( \pm \text { s.e.m. })^{\dagger}$ & $k_{\text {cat }}\left(\min ^{-1}\right)( \pm \text { s.e.m. })^{\dagger, \ddagger}$ \\
\hline wt & Abz-STRN $\downarrow$ GLPS-Y $\left(3 \mathrm{NO}_{2}\right)$ & $51.3( \pm 5.8)$ & $55.0( \pm 6.4)$ & $1.6( \pm 0.2)$ \\
\hline $\mathrm{R}_{28} \mathrm{~A}$ & Abz-STAN $\downarrow$ GLPS-Y $\left(3 \mathrm{NO}_{2}\right)$ & $6.9( \pm 0.6)$ & $13.0( \pm 2.4)$ & $0.2( \pm 0.02)$ \\
\hline $\mathrm{R}_{28} \mathrm{~K}$ & Abz-STKN $\downarrow$ GLPS-Y $\left(3 \mathrm{NO}_{2}\right)$ & $29.3( \pm 3.5)$ & $42.0( \pm 4.0)$ & $0.9( \pm 0.1)$ \\
\hline $\mathrm{N}_{29} \mathrm{~A}$ & Abz-STRA $\downarrow$ GLPS-Y $\left(3 \mathrm{NO}_{2}\right)$ & $N A^{\S}$ & - & - \\
\hline $\mathrm{N}_{29} \mathrm{Q}$ & Abz-STRQ $\downarrow$ GLPS-Y $\left(3 \mathrm{NO}_{2}\right)$ & $N A^{\S}$ & - & - \\
\hline $\mathrm{N}_{29} \mathrm{D}$ & Abz-STRD $\downarrow$ GLPS-Y $\left(3 \mathrm{NO}_{2}\right)$ & $\sim 2^{\|}$ & ND\|l & $\sim 0.06^{\|}$ \\
\hline $\mathrm{G}_{30} \mathrm{~A}$ & Abz-STRN $\downarrow$ ALPS-Y $\left(3 \mathrm{NO}_{2}\right)$ & $51.0( \pm 2.0)$ & $29.0( \pm 1.4)$ & $1.6( \pm 0.07)$ \\
\hline $\mathrm{G}_{30} \mathrm{~S}$ & Abz-STRN $\downarrow S L P S-Y\left(3 N_{2}\right)$ & $35.5( \pm 2.7)$ & $31.4( \pm 2.5)$ & $1.1( \pm 0.08)$ \\
\hline $\mathrm{L}_{31} \mathrm{~A}$ & $A b z-S T R N \downarrow G A P S-Y\left(3 N_{2}\right)$ & $N A^{\S}$ & - & - \\
\hline$L_{31} I$ & $\mathrm{Abz}-\mathrm{STRN} \downarrow \mathrm{GIPS}-\mathrm{Y}\left(3 \mathrm{NO}_{2}\right)$ & ND & ND & ND \\
\hline
\end{tabular}

IQF, internally quenched fluorescent; NA, no activity; ND, not determined.

*IQF peptide residues are numbered according to their position within the native $\mathrm{kB1}$ precursor, where the mature cyclotide incorporates $\mathrm{Gly}_{1}$-Asn 29 ; native $\mathrm{Cys}_{26}$ is substituted with Ser to avoid unpaired Cys residues.

$\dagger \mathrm{N} \geq 3$; \pm standard error of the mean (s.e.m.)

${ }^{\ddagger} k_{\text {cat }}$ is a conservative estimate assuming that the total concentration of active enzyme is equal to the total protein concentration in the enzyme preparation and an enzyme mass of $32 \mathrm{kDa}$.

No activity detected under the conditions tested (up to $80 \mu \mathrm{M}$ substrate; up to $6 \mathrm{~h}$ incubation).

"Low $V_{\max }$ precluded accurate estimation of kinetic parameters.

${ }^{\top} K_{\mathrm{m}}$ above the range of the substrate concentrations used in this analysis precluded accurate estimation of kinetic parameters. 

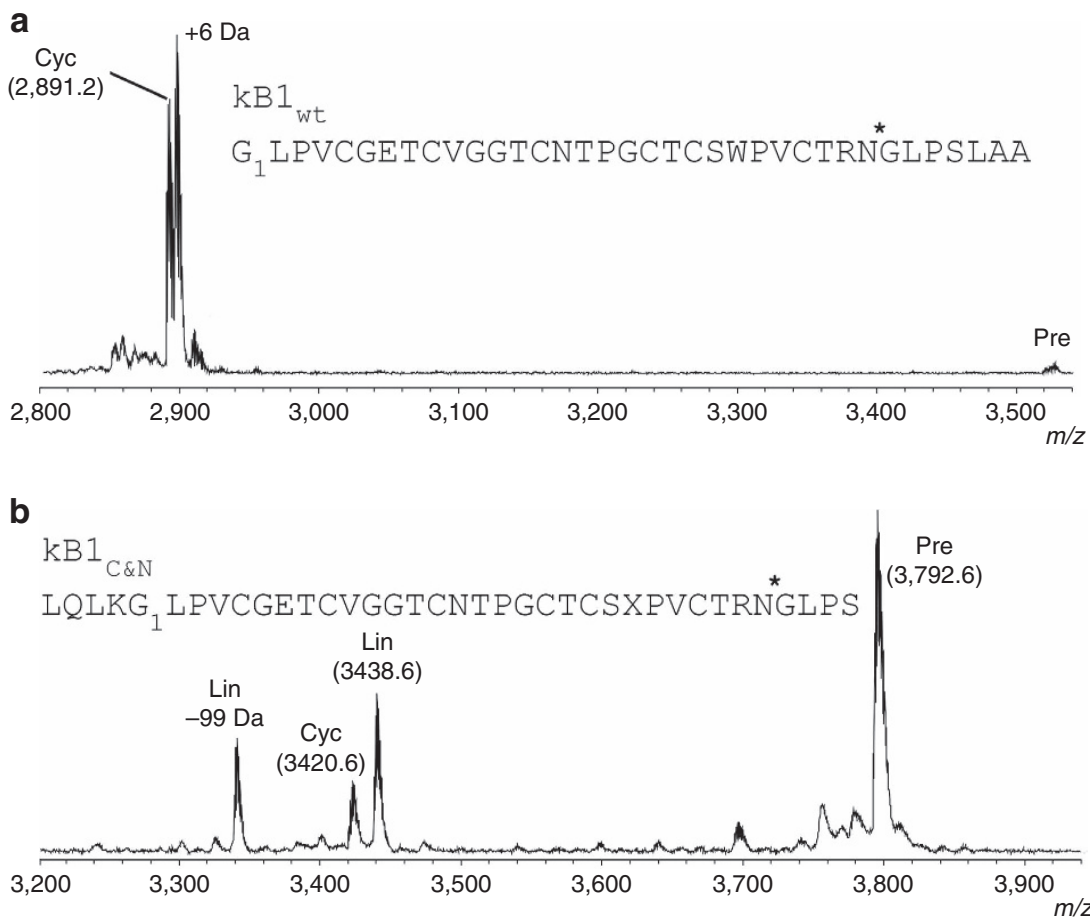

Figure 3 | Enzymatic processing products of linear kB1 precursors. (a) MALDI MS profile of a kB1 precursor ( $k B 1_{w t}$ ) containing the C-terminal propeptide in the presence of $\mathrm{raAEP}_{\mathrm{b}}(22 \mathrm{~h}$ incubation). The +6 Da peak was observed only in the presence of reducing agent and corresponds to the reduced form of cyclic kB1. (b) MALDI MS profile of a $\mathrm{kB1}$ precursor $\left(\mathrm{kB1} \mathrm{C} \& \mathrm{~N}_{\mathrm{N}}\right.$ ) containing four $\mathrm{C}$-terminal propeptide residues and four $\mathrm{N}$-terminal propeptide residues in the presence of $\mathrm{raAEP1}_{\mathrm{b}}(20.5 \mathrm{~h}$ incubation). A side product originating from chemical synthesis likely represents a Val deletion ( $-99 \mathrm{Da})$. Data are representative of at least two technical replicates. $X$, benzoylphenylalanine. ${ }^{\star}$ denotes $\mathrm{rOaAEP}_{\mathrm{b}}$ cleavage site. Observed monoisotopic masses (Da; $[\mathrm{M}+\mathrm{H}]^{+}$) for dominant peaks are listed. Cyc, cyclic product; Lin, linear product; Pre, linear precursor.

butelase $1\left(17.08 \mathrm{~s}^{-1}\right.$; ref. 5$)$, it is far higher than that of the recombinantly expressed cyclase PatG (1 per day; ref. 7 ).

To determine if $\mathrm{rOaAEP} 1_{\mathrm{b}}$ could also carry out the N-terminal processing required for cyclotide maturation, a $\mathrm{kB} 1$ precursor was tested that contained the folded cyclotide domain flanked by four residues from each of the $\mathrm{N}$ - and $\mathrm{C}$-terminal propeptides (Fig. 3b). No N-terminal processing was observed, indicating that this processing is conducted by an enzyme other than $O a \mathrm{AEP} 1_{\mathrm{b}}$. Although the bulk of the precursor remained intact after $20.5 \mathrm{~h}$, the predominant processing product was a linear peptide lacking the C-terminal propeptide, demonstrating that correct $\mathrm{N}$-terminal processing must occur before cyclization. Interestingly, a mass corresponding to a cyclized version of the C-terminally processed peptide (that is, C-terminal propeptide residues released, $\mathrm{N}$-terminal propeptide residues remaining) was also observed, although this was the least abundant product.

Processing of modified cyclotide precursors. To further probe cyclization requirements, we tested $\mathrm{rOaAEP} 1_{\mathrm{b}}$-mediated processing of modified $\mathrm{kB} 1$ and $\mathrm{kB} 2$ precursors over time (Fig. 4). When presented within an IQF peptide, the $\mathrm{Leu}_{31}$ Ala substrate analogue was not hydrolysed by $\mathrm{rOaAEP}_{\mathrm{b}}$ (Table 1 ). However, the same substitution within the $\mathrm{kB1}$ precursor did not preclude cyclization by $\mathrm{rOaAEP} 1_{\mathrm{b}}$, although this version was cyclized far more slowly than the wt precursor (Fig. 4a,b). Surprisingly, the presence of disulfide bonds in the cyclotide precursors is not a requirement for cyclization since a $\mathrm{kB1}$ substrate analogue in which all six cysteines were substituted with serines was also efficiently cyclized (Fig. 4c). The absence of a defined kB1-like structure in the $\mathrm{kBl}_{6 \mathrm{xS}}$ mutant was confirmed by NMR spectroscopy (Supplementary Fig. 7c). Similarly, a kB2 linear precursor with the same Cys $\rightarrow$ Ser substitutions was also efficiently cyclized, confirming that enzyme activity is not specific to individual cyclotides (Fig. 4d).

In cysteine protease-mediated peptide bond hydrolysis, nucleophilic attack of a water molecule is required to resolve the acyl-enzyme thioester intermediate. However, during peptide cyclization (or transpeptidation) the substrate's N-terminal amine is postulated to function as a competing nucleophile, facilitating aminolysis of the reactive thioester intermediate ${ }^{30}$. Accordingly, a $\mathrm{kB1}$ precursor with an acetyl-capped N-terminal amine was processed only to a linear peptide lacking the C-terminal propeptide (Fig. 4e). This hydrolysis occurred at a slower rate than cyclization of the wt precursor (compare with Fig. 4a). Water can therefore access the active site of $\mathrm{rOaAEP} 1_{\mathrm{b}}$, but cyclization is favoured over hydrolysis in the presence of an appropriately positioned nucleophile.

Water is excluded during cyclization. An alternative ligation mechanism, distinct from transpeptidation, was recently proposed for huLEG ${ }^{31}$ ). In that mechanism, initial hydrolysis of the C-terminal propeptide is followed by a separate ligation event requiring a C-terminal Asn residue in the substrate. To distinguish between these mechanisms in the case of $\mathrm{rOaAEP} 1_{\mathrm{b}}$, reactions were carried out in the presence of ${ }^{18} \mathrm{O}$ labelled water and the products were analysed by high-resolution MS. An isotopic shift consistent with the incorporation of ${ }^{18} \mathrm{O}$ was evident following enzymatic hydrolysis of the $\mathrm{N}$-terminal acetylated $\mathrm{kB1}$ precursor to give a linear product (Fig. 5a). However, there was no isotopic shift after processing of the wt precursor to a cyclic product, suggesting that hydrolysis is unlikely to play a role in cyclization by $\mathrm{rOaAEP}_{\mathrm{b}}$ (Fig. $5 \mathrm{a}$ ). 


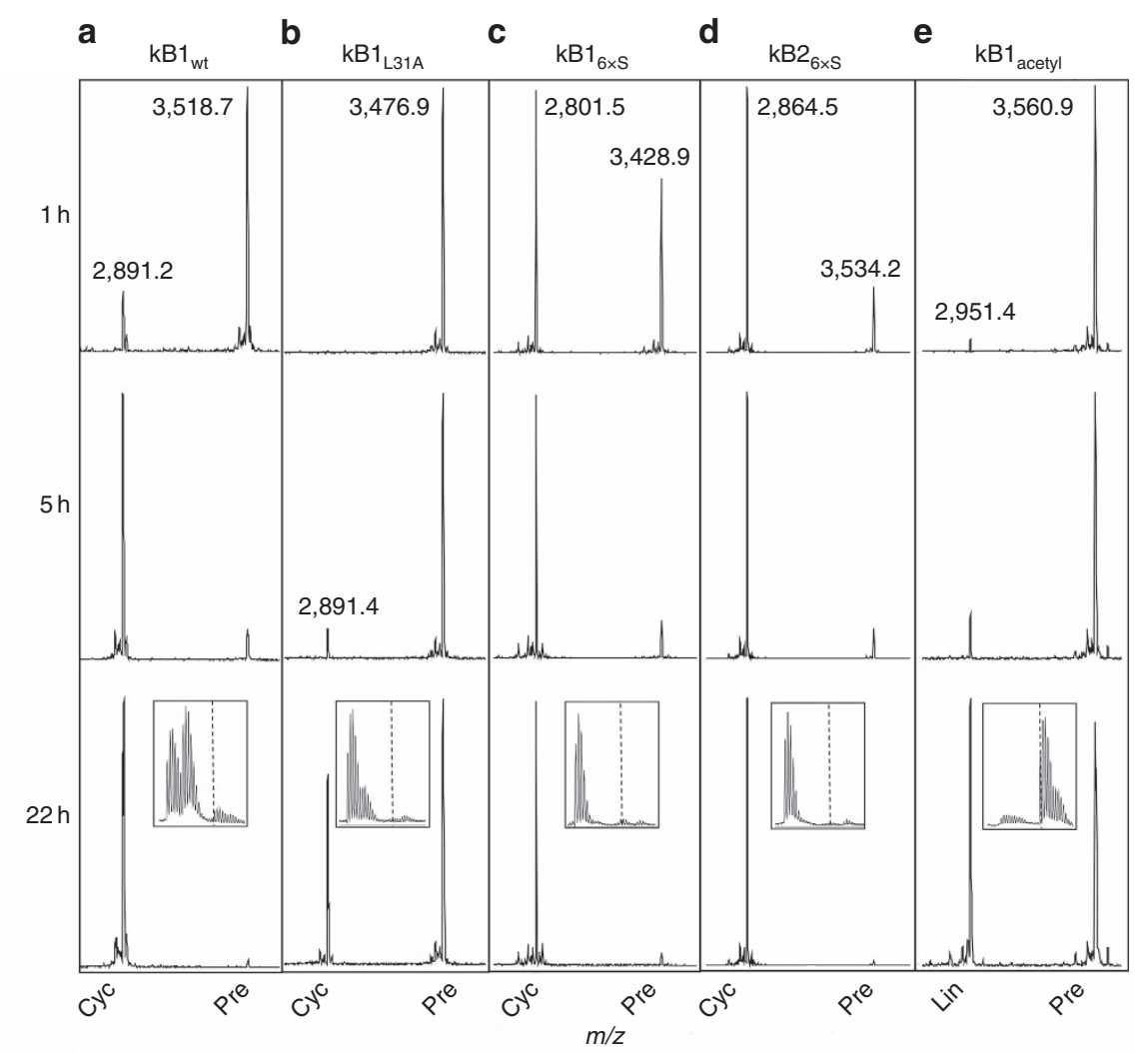

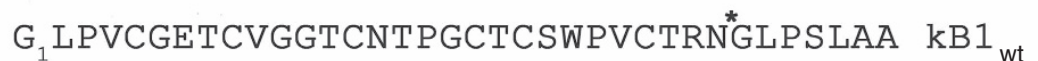

$$
\begin{aligned}
& \text { G LPVCGETCVGGTCNTPGCTCSWPVCTRNGAPSLAA } \mathrm{kB}_{\text {L31A }}
\end{aligned}
$$

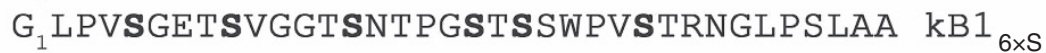

$$
\begin{aligned}
& \text { G_LPVSGETSFGGTSNTPGSSSTWPISTRDSLPLVAA kB2 } 6 \times 5 \\
& \text { AcG }_{1} \text { LPVCGETCVGGTCNTPGCTCSWPVCTRNGLPSLAA } \mathrm{kB}_{\text {acetyl }}
\end{aligned}
$$

Figure 4 | Modified linear kB1 and kB2 precursors are cyclized at different rates. MALDI MS spectra of (a) $k B 1_{w t}(\mathbf{b}) k B 1_{L 31 A},(\mathbf{c}) k B 1_{6 \times S},(d) k B 2_{6 \times S}$ and (e) $\mathrm{kB}_{\text {acetyl }}$ cyclotide precursors at 1,5 and $22 \mathrm{~h}$ post-enzyme addition. Data are representative of three technical replicates. ${ }^{\star}$ denotes rOaAEP1 $\mathrm{b}_{\mathrm{b}}$ cleavage site. Observed monoisotopic masses $\left(\mathrm{Da} ;[\mathrm{M}+\mathrm{H}]^{+}\right.$) for dominant peaks are listed. Boxed inset at the $22 \mathrm{~h}$ time point zooms in on the region containing the processing product. Approximate positions of the monoisotopic mass of processed products is indicated by :. Cyc, cyclic product; Lin, linear product; Pre, linear precursor.
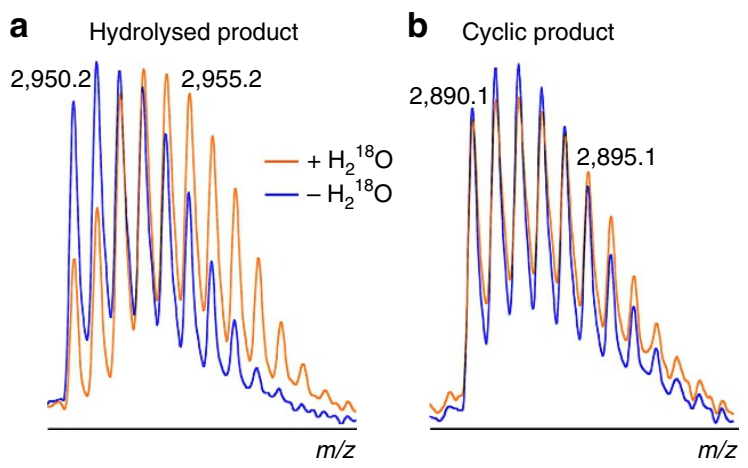

Figure 5 | Enzymatic cyclization excludes water. MALDI MS profile of the enzymatic processing products of (a) $k B 1_{\text {acetyl }}$ and (b) $k B 1_{w t}$ linear precursors in the presence and absence of ${ }^{18} \mathrm{O}$-labelled water. An isotope shift indicative of ${ }^{18} \mathrm{O}$ incorporation only occurs during hydrolysis. Observed masses of two isotopic peaks $\left(\mathrm{Da} ;[\mathrm{M}+\mathrm{H}]^{+}\right)$are indicated. Data are representative of three technical replicates.
rOaAEP1 $b$ can cyclise an unrelated peptide. We also investigated cyclization of other substrates structurally unrelated to cyclotides by $\mathrm{rOaAEP} 1_{\mathrm{b}}$, focussing on the anti-malarial peptide R1 (refs 32,33). This peptide was efficiently cyclized following the addition of $\mathrm{N}$ - and C-terminal AEP recognition sequences (Fig. 6a). Sequential trimming of the added recognition residues revealed that cyclization could be achieved following the addition of only a C-terminal Asn-GlyLeu motif (although some linear product was also produced from this precursor) (Figs $6 \mathrm{a}-\mathrm{d}$ ). Lys and $\mathrm{Gln}$ were also accepted in place of Gly at the $\mathrm{N}$ terminus (Figs $6 \mathrm{e}-\mathrm{f}$ ) with little impact on yield at the time point tested. No processing of either the native R1 peptide or a modified R1 carrying the $\mathrm{N}$-terminal Gly-Leu motif with only an Asn at the C terminus was observed (Supplementary Fig. 9). Subsequent digestion with endoGlu-C confirmed that, in all cases, $\mathrm{rOaAEP} 1_{\mathrm{b}}$ processing produced cyclic peptide (Supplementary Fig. 10). Evidence of an additional, linear, $\mathrm{rOaAEP} 1_{\mathrm{b}}$-generated cleavage product was only observed for the R1 variant without any N-terminal flanking residues (Fig. 6d; Supplementary Fig. 10c). 
a

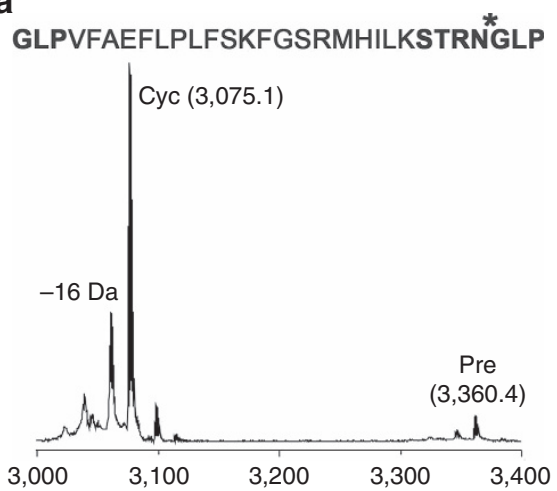

C

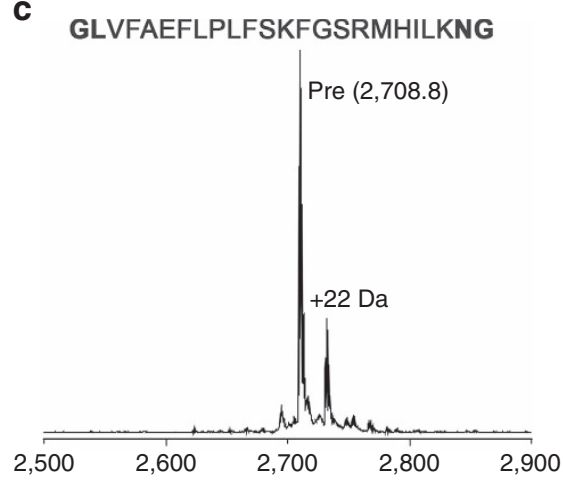

e QLVFAEFLPLFSKFGSRMHILKN ${ }^{*}$ GL

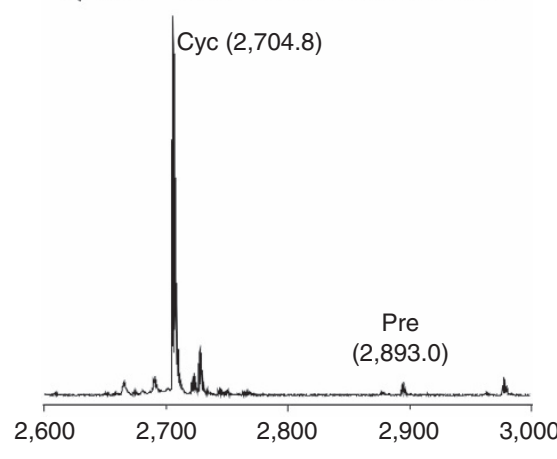

b

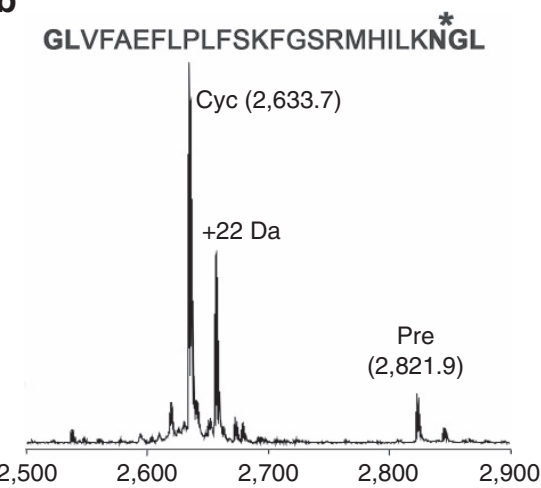

d VFAEFLPLFSKFGSRMHILKN"EL
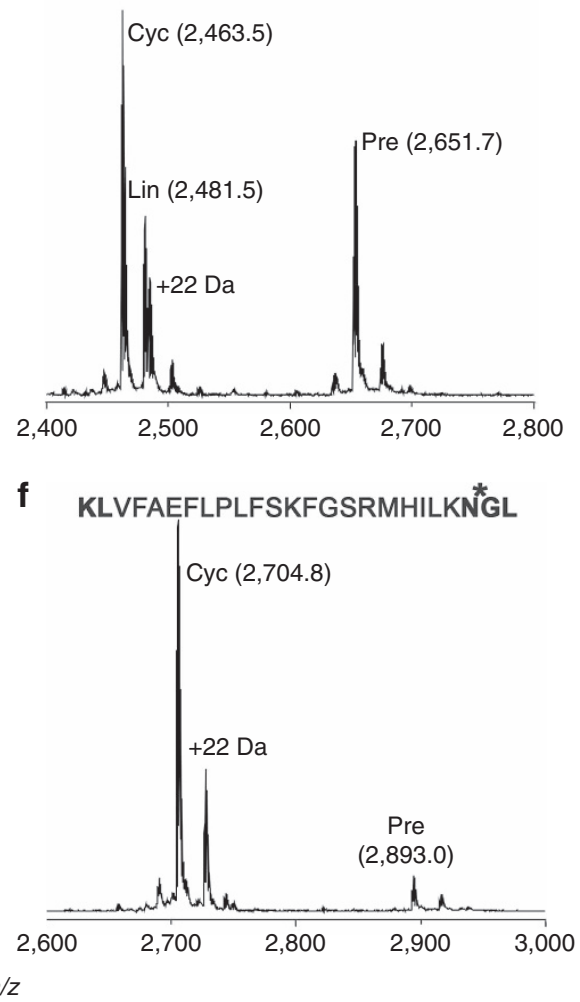

Figure 6 | Flanking sequence requirements for cyclization of a model peptide by rOaAEP1. (a-f). MALDI MS spectra of the R1 peptide (VFAEFLPLFSKFGSRMHILK) with various flanking sequences $22 \mathrm{~h}$ post addition of $\mathrm{rOaAEP}_{\mathrm{b}}$. Bold residues, flanking sequences. *denotes $\mathrm{rOaAEP}_{\mathrm{b}}$ cleavage site. Observed monoiosotopic masses $\left(\mathrm{Da} ;[\mathrm{M}+\mathrm{H}]^{+}\right)$are listed. $+22 \mathrm{Da}$ and $-16 \mathrm{Da}$ peaks present in some precursor and product spectra are likely to represent $\mathrm{Na}^{+}$adducts and a synthesis-derived modification respectively. Data are representative of three technical replicates. Cyc, cyclic product; Lin, linear product; Pre, linear precursor.

\section{Discussion}

This study reports the cloning of four AEPs from the cyclotideproducing plant $O$. affinis; one of which was recombinantly expressed. The recombinant enzyme required self-processing to produce the active product: a cyclase that preferentially and efficiently couples C-terminal processing with $\mathrm{C}$ - and $\mathrm{N}$-terminal ligation of linear O. affinis cyclotide precursors. Furthermore, this cyclizing ability was highly efficient when transferred to an unrelated anti-malarial peptide, demonstrating broad applicability in peptide engineering.

Consistent with other auto-inhibited proteases, $\mathrm{rOaAEP} 1_{\mathrm{b}}$ required proteolytic activation to achieve maximum activity (Fig. 2b). The observed N-terminal auto-processing site (Asp52) is consistent with other experimentally validated $\mathrm{N}$-terminal auto-processing sites identified in jack bean $\mathrm{AEP}^{34}$, butelase 1 (ref. 5) and human legumain ${ }^{28,35}$ (Fig. 2a, Supplementary Fig. 1). In contrast, six potential C-terminal auto-processing sites (Asp328/334/349/351, Asn329/336) were observed within a region particularly rich in Asn/Asp residues (324-351). This finding is in agreement with the multiple $\mathrm{C}$-terminal maturation steps recently described for rhuLEG ${ }^{28,35}$. Regardless of which of these sites is relevant in planta, the instability of active AEPs above $\mathrm{pH} 6$ (refs 28,29,36) will likely preclude direct production of active enzyme in $E$. coli. Activated $\mathrm{rOaAEP} 1_{\mathrm{b}}$ proteolytically removed the $\mathrm{C}$-terminal (but not $\mathrm{N}$-terminal) propeptide of a $\mathrm{kB1}$ precursor and resolved the acyl-intermediate in a hydrolysis-independent manner, generating a backbone cyclized product (Figs 3 and 5). rOaAEP1 $1_{\mathrm{b}}$ could also hydrolyse precursors lacking a free $\mathrm{N}$-terminal amine to produce linear products, albeit at a slower rate. Although it is unknown if 
$O a \mathrm{AEP} 1_{\mathrm{b}}$ performs both these cyclase and protease activities in vivo, the observed preference for cyclization over hydrolysis suggests that it probably functions predominantly as a cyclase.

Dual protease/ligase capabilities have been reported for $\mathrm{PatG}^{37}$, a serine protease involved in cyclic peptide production in cyanobacteria, and more recently for human legumain ${ }^{31}$. Separate mechanistic pathways for hydrolysis and ligation have been proposed for human legumain: proteolysis proceeds via hydrolysis of a cysteinyl-thioester enzyme intermediate, whereas peptide ligation occurs via activation of the free peptidyl- $\alpha$ carboxylate through transient formation of an enzyme-linked anhydride intermediate that is subsequently resolved via aminolysis ${ }^{31}$. The catalytically critical residue for this mechanism of ligation, Asp188, is conserved in $O a A E P 1_{b}$, but several lines of evidence preclude a role for this pathway in $O a A E P 1_{b}$-mediated peptide cyclization. First, $\mathrm{rOaAEP} 1_{\mathrm{b}}$ cannot cyclize peptides carrying a free C-terminal Asn, the minimal proposed substrate requirement in the alternative pathway (Supplementary Fig. 9). Second, our $\mathrm{H}_{2}^{18} \mathrm{O}$ experiments demonstrate the absence of ${ }^{18} \mathrm{O}$ incorporation into the cyclized product, which strongly indicates that cyclization does not follow a hydrolysis/ligation mechanism as proposed in the alternative pathway (Fig. 5). Third, our MS/MS data for $\mathrm{rOaAEP}_{\mathrm{b}}$ show no evidence of a reactive succinimide enzyme intermediate required for formation of the substrate-enzyme anhydrides ${ }^{31}$. Hence, our mechanistic data are in agreement with the traditional concerted mechanism, in which some of the energy from the (exergonic) cleavage of the C-terminal Asn-propeptide bond is preserved in the form of a thioester intermediate and used to overcome the energetically unfavourable (endergonic) peptide bond formation (cyclization) in the second step. However, alternative mechanisms may still play a role in cyclization mediated by other AEPs or with alternative substrates.

In the context of this established mechanism, C- and $\mathrm{N}$-terminal proximity was thought to be crucial for cyclization to be favoured over hydrolysis ${ }^{8}$. Here we show that pre-organization of $\mathrm{C}$ - and $\mathrm{N}$-termini in the substrate is not required by $\mathrm{rOaAEP} 1_{\mathrm{b}}$ since unconstrained cyclotide precursors lacking the characteristic disulfide-bonded structure are efficiently cyclized (Fig. 4). Furthermore, $\mathrm{rOaAEP}_{\mathrm{b}}$ can cyclize an anti-malarial peptide that is structurally and functionally unrelated to cyclotides following the addition of short flanking sequences (Fig. 6). These findings are consistent with the limited structural and/or sequence requirements imposed by other native cyclases on their substrates ${ }^{4,5,7}$ Conceivably, polypeptides of diverse composition and length may be cyclized by $\mathrm{rOaAEP} 1_{\mathrm{b}}$, provided that association of the $\mathrm{C}$ - and $\mathrm{N}$-termini is not sterically hindered.

The application of this technology is limited to peptides that can retain activity following incorporation of the additional residues required for AEP-mediated processing. While $\mathrm{rOaAEP} 1_{\mathrm{b}}$ can cyclize a model peptide with only a single non-native residue incorporated to the mature peptide, this is at the cost of cyclization efficiency (Fig. 6d). Understanding the interplay between the sequence requirements for efficient cyclization and retention of bioactivity for a given target peptide will be crucial to realizing the potential of AEP-mediated cyclization. Importantly, the estimated turnover rate of $\mathrm{rOaAEP}_{\mathrm{b}}\left(k_{\mathrm{cat}}, 0.53 \mathrm{~s}^{-1}\right.$; Supplementary Fig. 8) is multiple orders of magnitude higher than the recombinantly produced cyclase PatG $\left(1 \mathrm{~d}^{-1}\right.$; ref. 7$)$, supporting its widespread application in peptide engineering.

In a previous study, a conserved tripeptide motif $\mathrm{C}$ terminal to both the $\mathrm{N}$ - and $\mathrm{C}$-terminal cyclotide processing sites was identified through cyclotide sequence analysis ${ }^{8}$. This motif is Gly-Leu-Pro in the kB1 sequence, and its importance for efficient cyclization is supported by mutagenesis studies in transgenic plants ${ }^{8,21}$. The protease specificity of $\mathrm{rOaAEP} 1_{\mathrm{b}}$ reported here against IQF peptides mirrors these requirements (Table 1). At the C-terminal processing site, the P1 Asn and $\mathrm{P}^{\prime}$ Leu are particularly well-conserved, and both were crucial for both in planta cyclization and in vitro cleavage of model peptides. However, over the longer incubation period of the cyclization assays, a kB1 precursor with a Leu $_{31} \mathrm{Ala}$ mutation was still enzymatically processed to a cyclic product (Fig. 4). It was initially proposed that the conserved Leu residue at the $\mathrm{P}^{\prime}$ position of cyclotides was important for preventing water from accessing the active site during cyclization. However the observed cyclization of the $\mathrm{kB1} \mathrm{Leu}_{31}$ Ala mutant suggests that the role of a conserved bulky hydrophobic residue at the $\mathrm{P}^{2}$ position is only to promote appropriate enzyme-substrate interaction. Congruent with this hypothesis, the absence of a $\mathrm{P}^{\prime}$ residue renders substrates poor targets of both $\mathrm{rOaAEPl}_{\mathrm{b}}$ (cyclization and hydrolysis; Fig. 6c; Supplementary Fig. 5) and butelase 1 (at least for hydrolysis ${ }^{5}$. In summary, our results suggest a cyclization model in which the cleaved C-terminal propeptide retains sufficient affinity to remain bound to the active site until it is displaced by the incoming $\mathrm{N}$ terminus of the peptide, finally leading to cyclization by resolving the acyl intermediate 8,38 .

This $\mathrm{P}^{\prime}$ requirement is not characteristic of all AEPs ${ }^{9,34,39}$ and might be a predictor of cyclization ability within this protease family. Indeed, in extracts from C. ternatea, protein fractions that were active against the generic AEP substrate Z-AAN-MCA (which does not contain a $\mathrm{P}^{\prime}$ residue) did not contain the cyclizing enzyme and, conversely, the butelase 1 containing fraction did not display activity against this substrate ${ }^{5}$. Here we report the presence of four unique AEP sequences in O. affinis (Fig. 2a; Supplementary Fig. 1), and demonstrate that one $\left(O a \mathrm{AEP}_{\mathrm{b}}\right)$ is capable of cyclizing O. affinis cyclotide precursors. Further work will investigate whether all, or a subset of, O. affinis AEPs (at least two more of which should exist to explain all the AEP contig sequences observed) exhibit this function and whether their substrate specificity is an accurate predictor of cyclization ability.

The constraints on the sequence of the incoming $\mathrm{N}$ terminus may not be very stringent. At least two residues with different properties are accepted in place of Gly at the $\mathrm{P}^{\prime \prime}$ position by $\mathrm{rOaAEP} 1_{\mathrm{b}}$ with comparable yields of cyclic product under the conditions tested (Fig. 6e,f). Butelase 1 and Pat G also exhibit promiscuity in this region ${ }^{5,37}$. Interestingly, $\mathrm{Gly}_{1}$ is highly conserved across cyclotides from different plant species, raising the possibility that selection at this position is not driven by AEP cyclase specificity. In transgenic plants, more stringent requisites were observed and no cyclic product was made from $\mathrm{kB1}$ precursors with a conservative Gly ${ }_{1}$ Ala mutation ${ }^{8}$. Because AEP cannot liberate the $\mathrm{N}$-terminal propeptide, we hypothesize that selection at $\mathrm{Gly}_{1}$ might be driven by the putative N-terminal processing enzyme. Further analysis will be necessary to determine if this reflects differences in the enzyme homologues being assayed (that is, AEPs from the model plant Nicotiana benthamiana compared with AEPs from native cyclotide producers) or experimental conditions.

In conclusion, this study unequivocally demonstrates the involvement of an AEP in maturation of native $O$. affinis cyclotides, advancing our understanding of the biosynthesis of this important class of cyclic peptides. Furthermore, the promiscuous yet highly efficient nature of this recombinantly produced enzyme highlights its exciting potential value as a biological tool for cyclization of a range of bioactive peptides.

\footnotetext{
Methods

Peptide substrates and inhibitors. IQF peptides containing an N-terminal
} $o$-aminobenzoic acid (Abz) group and a C-terminal 3-nitrotyrosine $\left(\mathrm{Y}\left[3 \mathrm{NO}_{2}\right]\right)$ 
were synthesized by Genscript at $>90 \%$ purity. Control IQF peptides representing the predicted cleavage products of the wt peptide (Abz-STRN; GLPS-Y $\left(3 \mathrm{NO}_{2}\right)$ were also synthesized by Genscript at $>90 \%$ purity. All IQF peptides were solubilized in $25 \%(\mathrm{v} / \mathrm{v})$ acetonitrile:water. The fluorogenic peptide substrate Z-AANMCA (where $\mathrm{Z}$ is carboxybenzyl; MCA is 7-amido-4-methylcoumarin) and the caspase inhibitor Ac-YVAD-CHO (where Ac, acetyl; CHO, aldehyde) were supplied by the Peptide Institute and solubilized in dimethyl sulfoxide. The linear cyclotide precursor peptides $\mathrm{kB}_{\mathrm{wt}}, \mathrm{kB}_{\mathrm{C} \& \mathrm{~N}}, \mathrm{kB}_{\mathrm{L} 31 \mathrm{~A}}$ and $\mathrm{kB1} 1_{\text {acetyl }}$ were chemically synthesized in-house by standard Fmoc solid-phase peptide synthesis. Folding and disulfide formation was carried out by incubating the reduced peptides in folding buffer ( $100 \mathrm{mM}$ ammonium bicarbonate, $50 \%$ isopropanol, $2 \mathrm{mM}$ reduced glutathione, $1 \mathrm{mM}$ oxidized glutathione, $\mathrm{pH}$ 8.2) for 3 days $^{40}$. The products were isolated by RP-HPLC at $>95 \%$ purity and characterized by high-resolution MS and NMR spectroscopy. Peptides $\mathrm{kB1}_{6 \mathrm{xS}}$ and $\mathrm{kB} 2_{6 \mathrm{xS}}$ as well as $\mathrm{R} 1$ and its derivatives were supplied by Genscript at $>85 \%$ purity, as determined by RP-HPLC and MS. Peptides were dissolved in ultrapure water before analysis.

O. affinis transcriptome. Total RNA was extracted from $O$. affinis root, leaf and seedling tissues using a phenol extraction method. Plant material was frozen in liquid nitrogen and ground to a fine powder, which was then resuspended in buffer (0.1 M Tris-HCl pH 8.0, 5 mM EDTA, $0.1 \mathrm{M} \mathrm{NaCl}, 0.5 \%$ SDS, $1 \%$ 2-mercaptoethanol), extracted twice with 1:1 phenol:chloroform and precipitated by addition of isopropanol. The pellets were dissolved in $0.5 \mathrm{ml}$ water and RNA was precipitated overnight at $4{ }^{\circ} \mathrm{C}$ by addition of $4 \mathrm{M}$ lithium chloride. The extracted RNA of each tissue was analysed by GeneWorks using the Illumina GAIIx platform. In total, 69.3 million 75 bp paired-end reads were generated. Reads were filtered with a phred confidence value of Q37 and assembled into contigs using Oases ${ }^{41}$ with $\mathrm{k}$-mer ranging from 41-67. The assemblies were merged using cd-hit-est ${ }^{42}$, resulting in 270,000 contigs. Statistics on the depth of sequencing were made by aligning the reads of each tissue on the contigs using BWA ${ }^{43}$. All the sequences, including one AEP, previously identified from an EST library of $O$. affinis were present among the contigs ${ }^{44}$. Homologues of this AEP sequence were searched using BLAST ${ }^{45}$ in the contig library using a maximum E-value of 1e-20, resulting in the identification of 371 putative AEP transcripts. These sequences could then be clustered in 13 groups sharing at least $90 \%$ sequence identity using cd-hit ${ }^{42}$

OaAEP1-3 cloning. Full-length AEP transcripts from the O. affinis transcriptome assembly were used to design a set of primers. A single degenerate forward primer (OaAEPdegen-F, $5^{\prime}$-ATG GTT CGA TAT CYC GCC GG-3') was sufficient to amplify all sequences since variability within the extreme $5^{\prime}$ region of each fulllength transcript was limited to a single nucleotide position. Three reverse primers (OaAEP1-R, 5'-TCA TGA ACT AAA TCC TCC ATG GAA AGA GC-3'; OaAEP2-R, 5' $5^{\prime}$ TTA TGC ACT GAA TCC TTT ATG GAG GG-3'; OaAEP3-R $5^{\prime}$-TTA TGC ACT GAA TCC TCC ATC G-3') were designed with the aid of Primer 3 (ref. 46). Each primer set successfully amplified an AEP sequence.

To clone expressed OaAEPs, total RNA was extracted from O. affinis leaves and shoots using TRIzol (Life Technologies) and was reverse transcribed with SuperScript III reverse transcriptase (Life Technologies) according to the manufacturer's instructions ${ }^{11}$. Target sequences were amplified from the resulting complementary DNA using Phusion High Fidelity Polymerase (New England BioLabs) and the primers described above under the recommended reaction conditions. Gel extracted PCR products were dA-tailed by incubation with Invitrogen Taq Polymerase (Life Technologies) and $0.5 \mu \mathrm{l} 10 \mathrm{mM} \mathrm{dA}$ in the supplied buffer. The processed products were cloned into pCR8-TOPO (Life Technologies) and transformed into E. coli. Purified DNA from clones that were PCR positive for an AEP insert were sent for Sanger sequencing at the Australian Genome Research Facility (www.agrf.org). Coding sequences have been deposited in Genbank (accession codes: OaAEP1 (KR259377), OaAEP2 (KR259378), OaAEP3 (KR259379)).

In an alternative approach, genomic DNA was extracted from O. affinis leaf tissue using a DNeasy Plant Mini Kit according to the manufacturer's instructions. PCR amplification from this DNA used primers specifically targeting the OaAEP1 nucleotide sequence. Gel extracted product was dA-tailed as above, cloned into the TOPO vector and transformed into E. coli. Sequencing of PCR-positive clones identified a fourth sequence with a single amino acid change from OaAEP1 $\left(\mathrm{OaAEP} 1_{\mathrm{b}}\right)$.

Antibodies. Polyclonal anti- $O a \mathrm{AEP} 1_{\mathrm{b}}$ rabbit serum was generated by immunizing a New Zealand White rabbit with a denatured, inactive form of $O a A E P 1_{b}$ (residues $\mathrm{D}_{47}-\mathrm{P}_{474}$ ) that was produced recombinantly in E. coli. The rabbit received three doses, four weeks apart, of $150 \mu \mathrm{g}$ of antigen in $50 \%(\mathrm{v} / \mathrm{v})$ PBS and Freund's incomplete adjuvant. Serum was obtained 2 weeks after the final dose and used at a 1:2,000 dilution for Western blotting.

Recombinant expression of 0 . affinis AEP1 $1_{b}$ (rOaAEP1 ${ }_{b}$ ). Initial trials to produce active $O$. affinis $\mathrm{AEP}_{\mathrm{b}}$ based on predicted $\mathrm{N}$ - and C-terminal processing sites (residues $\mathrm{D}_{47}-\mathrm{D}_{420}$ ) were unsuccessful and subsequent expression attempts incorporated both N- and C-terminal prodomains. DNA encoding full-length
O. affinis $\mathrm{AEP}_{\mathrm{b}}$ without the putative signalling domain (residues $\mathrm{A}_{24}-\mathrm{P}_{474}$ ) was inserted into the pHUE vector ${ }^{47}$ to give a His6-ubiquitin-OaAEP1 $1_{\mathrm{b}}$ fusion protein construct (Supplementary Fig. 2) and introduced into T7 shuffle E. coli cells (New England BioLabs). Transformed cells were grown at $30^{\circ} \mathrm{C}$ in superbroth (3.5\% tryptone $(\mathrm{w} / \mathrm{v}), 2 \%$ yeast extract $(\mathrm{w} / \mathrm{v}), 1 \%$ glucose $(\mathrm{w} / \mathrm{v}), 90 \mathrm{mM} \mathrm{NaCl}, 5 \mathrm{mM}$ $\mathrm{NaOH}$ ) to mid-log phase; the temperature was then reduced to $16^{\circ} \mathrm{C}$ and expression was induced with isopropyl $\mathrm{B}-\mathrm{D}-1$-thiogalactopyranoside $(0.4 \mathrm{mM})$ for $\sim 20 \mathrm{~h}$. Cells were harvested by centrifugation and resuspended in non-denaturing lysis buffer ( $50 \mathrm{mM}$ Tris- $\mathrm{HCl}, 150 \mathrm{mM} \mathrm{NaCl}, 0.1 \%$ triton X 100 , $1 \mathrm{mM}$ EDTA, pH 7). Lysis was promoted by a total of five freeze/thaw cycles and the addition of lysozyme (hen egg white; $0.4 \mathrm{mg} \mathrm{ml}^{-1}$ ). DNase (bovine pancreas; $\left.40 \mu \mathrm{g} \mathrm{ml}^{-1}\right)$ and $\mathrm{MgCl}_{2}(0.4 \mathrm{M})$ were also added. Cellular debris was removed by centrifugation and the lysate was stored at $-80^{\circ} \mathrm{C}$ until required.

Purification and activation of rOaAEP1 $\mathbf{b}_{\mathbf{b}}$. Lysate containing expressed $\mathrm{rOaAEP} 1_{\mathrm{b}}$ was filtered through a $0.1 \mu \mathrm{m}$ glass fibre filter before being diluted 1:8 in buffer A ( $20 \mathrm{mM}$ bis-Tris, $0.2 \mathrm{M} \mathrm{NaCl}$, pH 7) and loaded onto two $5 \mathrm{ml} \mathrm{HiTrap} \mathrm{Q} \mathrm{Sepharose}$ high performance columns connected in series (GE Healthcare; 1.6-3.1 ml undiluted lysate per millilitre resin). Bound proteins were eluted with a continuous salt gradient $(0-30 \%$ buffer B $(20 \mathrm{mM}$ bis-Tris, $2 \mathrm{M} \mathrm{NaCl}, \mathrm{pH}$ 7); 15 column volumes) and AEP-positive fractions identified by Western blotting (anti-OaAEP1 rabbit serum (1:2,000); peroxidase-conjugated anti-rabbit IgG (GE Healthcare NA934; 1:5000)). To self-activate $\mathrm{rOaAEP} 1_{\mathrm{b}}$, EDTA $(1 \mathrm{mM})$ and Tris(2-carboxyethyl)phosphine hydrochloride $(0.5 \mathrm{mM})$ were added, the $\mathrm{pH}$ was adjusted to 4.5 with glacial acetic acid and the protein pool was incubated for $5 \mathrm{~h}$ at $37^{\circ} \mathrm{C}$. Protein precipitation at this $\mathrm{pH}$ allowed removal of the bulk of the contaminating proteins by centrifugation. The remaining protein was filtered $(0.22 \mu \mathrm{m})$, diluted $1: 8$ in buffer A2 $(50 \mathrm{mM}$ acetate, $\mathrm{pH} 4)$ then captured on a $1 \mathrm{ml}$ HiTrap SP Sepharose high performance column (GE Healthcare). Bound proteins were eluted with a salt gradient $(0-100 \%$ buffer B2 (50 $\mathrm{mM}$ acetate, $1 \mathrm{M} \mathrm{NaCl}, \mathrm{pH} 4) ; 10$ column volumes) and AEP-positive fractions were pooled. The final product was analysed by MS and reducing SDS-PAGE followed by Western blotting and staining with Instant blue (Expedeon). The total concentration of protein was estimated by bicinchoninic acid assay according to the manufacturer's instructions.

Identification of the auto-processing sites of rOaAEP1 $b_{\mathbf{b}}$. Aliquots of $\mathrm{rOaAEP} 1_{\mathrm{b}}$ $(5 \mu \mathrm{l})$ were diluted $1: 1$ with either $100 \mathrm{mM}$ ammonium bicarbonate $\mathrm{pH} 8.0$ (trypsin, chymotrypsin) or $100 \mathrm{mM}$ ammonium phosphate $\mathrm{pH} 8.0$ (endoGlu-C) and enzymatically digested with endoGlu-C, trypsin or chymotrypsin $\left(100 \mathrm{ng}^{-1} \mathrm{l}^{-1}\right.$ ). Cleavages were conducted over $16 \mathrm{~h}$ at $37^{\circ} \mathrm{C}$ (endoGlu-C, trypsin) or $30^{\circ} \mathrm{C}$ (chymotrypsin). Injections of each digest $(5 \mu \mathrm{l})$ were introduced to a Shimadzu nanoLC delivering a linear acetonitrile gradient at a flow rate of $500 \mathrm{nl} \mathrm{min}^{-1}$ for reversed-phase separation on a C18 Zorbax column (Agilent 300SB-C18, $3.5 \mu \mathrm{m}$ particle size, $150 \mathrm{~mm} \times 100 \mu \mathrm{m}$ ). Column eluate was interfaced directly with a 5600 TripleTOF LC-MS/MS instrument (AB SCIEX, Canada) equipped with a nanoelectrospray ionization source.

Tandem MS data were generated in Information Dependent Acquisition experiments, wherein full-scan TOF-MS spectra were acquired for $250 \mathrm{~ms}$ over $\mathrm{m} / \mathrm{z}$ $350-1,800$, and the 20 most intense signals with charge state +2 to +5 were selected for product ion scans of duration $50 \mathrm{~ms}$ over $\mathrm{m} / z$ 80-1,400. Data were acquired and processed using the Analyst TF 1.6 software (AB SCIEX, Canada). Automated protein identification was performed in ProteinPilot 4.0 using the Paragon algorithm with 'no enzyme' settings to interrogate an E. coli K12 proteome database (Uniprot) concatenated with sequences of $\mathrm{rOaAEP} 1_{\mathrm{b}}$ and those of the three cleavage enzymes, with false discovery rate set at $P<0.05$. Spectral data for peptides software matched to $\mathrm{rOaAEP} 1_{\mathrm{b}}$ were confirmed via manual interpretation in Analyst TF 1.6.

Assaying protease activity against fluorescent peptides. To assay activity of $\mathrm{rOaAEP} 1_{\mathrm{b}}$ against both internally quenched and other fluorescent peptides, substrate and enzyme were diluted as appropriate in activity buffer $(50 \mathrm{mM}$ sodium acetate, $50 \mathrm{mM} \mathrm{NaCl}, 1 \mathrm{mM}$ EDTA, $0.5 \mu \mathrm{M}$ Tris(2-carboxyethyl)phosphine hydrochloride, $\mathrm{pH} 5$ ). To assay activity of rhuLEG (R\&D systems) against the same substrates, the enzyme was first activated by incubation in $50 \mathrm{mM}$ sodium acetate, $100 \mathrm{mM} \mathrm{NaCl}, \mathrm{pH} 4$ ( $4 \mu \mathrm{l}$ buffer $/ 1 \mu \mathrm{l}$ enzyme) for $2 \mathrm{~h}$ at $37^{\circ} \mathrm{C}$. Substrates and activated rhuLEG were diluted in $50 \mathrm{mM}$ MES, $250 \mathrm{mM} \mathrm{NaCl}, \mathrm{pH} 5$ as required. Diluted enzyme and substrate were added to black, flat bottomed microtiter plates in a total assay volume of $110-200 \mu$. The change in fluorescence intensity over time was monitored on a SpectraMax M2 (Molecular Devices) using excitation/ emission wavelengths of $320 / 420 \mathrm{~nm}$ (IQF peptides) or $360 / 460 \mathrm{~nm}$ (other fluorescent peptides). Substrate and enzyme concentrations in each assay and the time point presented are as indicated in the figure legends.

To determine the kinetics of $\mathrm{rOaAEP} 1_{\mathrm{b}}$ activity against IQF peptides, each substrate was assayed at a range of concentrations between 2.5 and $80 \mu \mathrm{M}$ in a total volume of $200 \mu$ l. The total protein concentration of the enzyme preparation used in the kinetic assays was $3.5 \mu \mathrm{g} \mathrm{ml}^{-1}$. It was not possible to precisely determine the concentration of active enzyme due to impurities remaining in the preparation and the absence of an inhibitor appropriate for active site titration. However, a conservative turnover rate $\left(k_{\text {cat }}\right)$ was estimated based on a mass of $32 \mathrm{kDa}$ and 
the assumption that the total protein concentration reflected active enzyme. At each substrate concentration, initial velocities were calculated from the linear portion of the progress curve. $K_{\mathrm{m}}$ and $V_{\max }$ were estimated using the MichaelisMenten equation and the curve-fitting program GraphPad Prism (GraphPad Software, San Diego).

The high peptide concentrations required for estimating kinetic parameters necessitated the use of a correction factor to account for the inner filter effect; a phenomenon where high relative concentrations of the quenching group impede detection of the signal from the fluorescent donor even after substrate hydrolysis ${ }^{48}$. This was achieved as described previously ${ }^{48}$. The output generated by the fluorescent hydrolysis product (Abz-STRN) was measured in the presence of each concentration of non-hydrolysed substrate. The correction factor was the ratio between the expected and observed fluorescence signal at each substrate concentration. The corrected signal for each data point was then converted to amount of product by comparison to a standard curve of the fluorescent hydrolysis product.

Inhibition assays. To investigate the impact of inhibitors on enzyme activity against the wt IQF peptide, $\mathrm{rOaAEP} 1_{\mathrm{b}}\left(4.4 \mu \mathrm{g} \mathrm{ml}^{-1}\right.$ total protein) was incubated with the indicated concentration of E64, Ac-YVAD-CHO, pepstatin A and iodoacetamide for $40 \mathrm{~min}$ before addition to the substrate $(11 \mu \mathrm{M})$. Enzyme activity against the wt IQF peptide was then assessed as described above.

Cyclization assay. Linear target peptides $(280 \mu \mathrm{M})$ were incubated with $\mathrm{rOaAEP} 1_{\mathrm{b}}\left(12 \mu \mathrm{g} \mathrm{ml}^{-1}\right.$ total protein unless otherwise indicated) in activity buffer. The reaction was allowed to proceed for up to $22 \mathrm{~h}$ at room temperature and was analysed by matrix-assisted laser desorption/ionization MS (MALDI MS), RP-HPLC or NMR as appropriate.

To confirm the presence of cyclic product, $\mathrm{R} 1$ derivatives processed by $\mathrm{rOaAEP} 1_{\mathrm{b}}$ were subsequently digested with endoGlu-C $\left(25 \mu \mathrm{g} \mathrm{ml}^{-1}\right)$ in reaction buffer (50 mM Tris-HCl, $0.5 \mathrm{mM}$ Glu-Glu, $\mathrm{pH}$ 8) such that the final dilution of the cyclization mix was 1:4. The reaction was allowed to proceed for $18 \mathrm{~h}$ at $37^{\circ} \mathrm{C}$ before analysis by MALDI MS.

In heavy water experiments, isotopically labelled water $\left(97\right.$ atom $\left.\%{ }^{18} \mathrm{O}\right)$ was used in place of unlabelled water. Linear target peptides $(70 \mu \mathrm{M})$ were incubated with $\mathrm{rOaAEP} 1_{\mathrm{b}}\left(6 \mu \mathrm{g} \mathrm{ml}^{-1}\right.$ total protein) in a non-reducing activity buffer $(50 \mathrm{mM}$ sodium acetate, $50 \mathrm{mM} \mathrm{NaCl}, 1 \mathrm{mM} \mathrm{EDTA}, \mathrm{pH}$ 5) for $22 \mathrm{~h}$ at room temperature. The final $\mathrm{H}_{2}^{18} \mathrm{O}$ concentration in the assay was $81 \%$.

MS to track cyclization of linear peptides. Cyclization of linear target peptides was monitored by MALDI MS. The reaction mixture $(10-20 \mu \mathrm{l})$ was desalted using C18 zip tips and eluted in $4 \mu \mathrm{l} 50 \%$ acetonitrile, $0.1 \%$ trifluoroacetic acid (TFA). A saturated MALDI matrix solution ( $\alpha$-cyano-4-hyroxycinnamic acid) prepared in 95\% acetonitrile, $0.1 \%$ TFA was diluted 1:22 such that the final matrix solution comprised $90 \%$ acetonitrile, $0.1 \%$ TFA and $1 \mathrm{mM} \mathrm{NH}_{4} \mathrm{H}_{2} \mathrm{PO}_{4}$. Eluted samples were mixed 1:4 with the MALDI matrix, spotted onto a MALDI plate and analysed by an Ultraflex III TOF/TOF (Bruker) in positive reflector mode.

Purification of kB1 following in vitro cyclization. The crude cyclization mixture was loaded to an Agilent Zorbax C18 reversed-phase column $(4.6 \times 250 \mathrm{~mm}$, $300 \AA$ ) and separated on a Shimadzu Prominence system using a linear gradient of $5-55 \%$ buffer B ( $90 \%$ acetonitrile, $10 \% \mathrm{H}_{2} \mathrm{O}, 0.05 \%$ TFA) in buffer A $(0.05 \%$ TFA $/ \mathrm{H}_{2} \mathrm{O}$ ) over $60 \mathrm{~min}$. Fractions were collected manually, analysed by MALDI MS essentially as described above and lyophilized. Analytical HPLC and co-elution studies with chemically synthesized $\mathrm{kB} 1$ were carried out as described above.

Nuclear magnetic resonance spectroscopy. All peptides were dissolved in $90 \%$ $\mathrm{H}_{2} \mathrm{O} / 10 \% \mathrm{D}_{2} \mathrm{O}$ at a concentration of $\sim 2.0 \mathrm{mg} \mathrm{ml}^{-1}(0.5-0.75 \mathrm{mM})$. $\mathrm{kB1}$ obtained from in vitro cyclizations was dissolved at $0.3 \mathrm{mg} \mathrm{ml}^{-1}(\sim 0.1 \mathrm{mM})$. Spectra were recorded on a Bruker Avance $600 \mathrm{MHz}$ spectrometer equipped with a cryoprobe at $298 \mathrm{~K}$. Phase-sensitive mode using time-proportional phase incrementation for quadrature detection in the $t_{1}$ dimension was used for all two-dimensional spectra. Excitation sculpting with gradients was used to achieve water suppression. NMR experiments included TOCSY using a MLEV-17 spin lock sequence with an $80 \mathrm{~ms}$ mixing time, and NOESY with a $200 \mathrm{~ms}$ mixing time. Spectra were recorded with 4,096 data points in the $F_{2}$ dimension and 512 increments in the $F_{1}$ dimension. The $t_{1}$ dimension was zero-filled to 1,024 real data points, and the $F_{1}$ and $F_{2}$ dimensions were multiplied by a sine-squared function before Fourier transformation. The spectra were referenced to the water signal at 4.77 p.p.m. at $298 \mathrm{~K}$. All spectra were processed using TopSpin (Bruker) and manually assigned with CCPNMR using the sequential assignment protocol.

Cyclization kinetics. To determine the kinetics of $\mathrm{rOaAEP} 1_{\mathrm{b}}$ activity against the wt $\mathrm{kB1}$ precursor, the substrate was assayed at room temperature at a range of concentrations between 75 and $250 \mu \mathrm{M}$ in a total volume of $20-160 \mu \mathrm{l}$ of activity buffer. The total protein concentration of the enzyme preparation added to the kinetic assays was $19.7 \mu \mathrm{g} \mathrm{ml}^{-1}$. The reaction was quenched after $5 \mathrm{~min}$ with $0.1 \%$ TFA and the volume adjusted to $800 \mu \mathrm{l}$. A volume of $700 \mu \mathrm{l}$ was loaded onto a reversed-phase C18 analytical column (Agilent Eclipse C18, $5 \mu \mathrm{m}, 4.6 \times 150 \mathrm{~mm}$ ) and peptides were separated by HPLC (19 min linear gradient of $12-60 \%$ acetonitrile, $0.1 \%$ TFA at $1 \mathrm{ml} \mathrm{min}^{-1}$ ). The identity of eluted peaks was confirmed using MALDI MS. The area under the curve corresponding to the precursor peptide was quantitated by comparison to a standard curve and initial velocities were calculated by converting this to $\mu$ moles product formed. Kinetic parameters were estimated using the Michaelis-Menten equation and the curve-fitting program GraphPad Prism (GraphPad Software, San Diego). As for the IQF peptides, it was not possible to precisely determine the concentration of active enzyme due to impurities remaining in the preparation and the absence of an inhibitor appropriate for active site titration. However, a conservative turnover rate $\left(k_{\text {cat }}\right)$ was estimated based on a mass of $32 \mathrm{kDa}$ and the assumption that the total protein concentration reflected active enzyme. Differences in enzyme preparations means these parameters are not directly comparable to those determined for the IQF peptides.

\section{References}

1. Sheldon, P. S., Keen, J. N. \& Bowles, D. J. Post-translational peptide bond formation during conconavalin A processing in vitro. Biochem. J. 320, 865-870 (1996).

2. Hanada, K., Yewdell, J. W. \& Yang, J. C. Immune recognition of a human renal cancer antigen through post-translational protein splicing. Nature 427, 1-5 (2004).

3. Mazmanian, S. K., Liu, G., Ton-That, H. \& Schneewind, O. Staphylococcus aureus Sortase, an enzyme that anchors surface proteins to the cell wall. Science 285, 760-763 (1999).

4. Barber, C. J. S. et al. The two-step biosynthesis of cyclic peptides from linear precursors in a member of the plant family Caryophyllaceae involves cyclization by a serine protease-like enzyme. J. Biol. Chem. 288, 12500-12510 (2013).

5. Nguyen, G. K. T. et al. Butelase 1 is an Asx-specific ligase enabling peptide macrocyclization and synthesis. Nat. Chem. Biol. 10, 732-738 (2014).

6. Luo, H. et al. Peptide macrocyclization catalyzed by a prolyl oligopeptidase involved in $\alpha$-amanitin biosynthesis. Chem. Biol. 21, 1610-1617 (2014).

7. Lee, J., Mcintosh, J., Hathaway, B. J. \& Schmidt, E. W. Using marine natural products to discover a protease that catalyzes peptide macrocyclization of diverse substrates. J. Am. Chem. Soc. 131, 2122-2124 (2009).

8. Gillon, A. D. et al. Biosynthesis of circular proteins in plants. Plant J. 53, 505-515 (2008).

9. Saska, I. et al. An asparaginyl endopeptidase mediates in vivo protein backbone cyclization. J. Biol. Chem. 282, 29721-29728 (2007).

10. Bernath-Levin, K. et al. Peptide macrocyclization by a bifunctional endoprotease. Chem. Biol. 22, 571-582 (2015).

11. Jennings, C., West, J., Waine, C., Craik, D. \& Anderson, M. Biosynthesis and insecticidal properties of plant cyclotides: the cyclic knotted proteins from Oldenlandia affinis. Proc. Natl Acad. Sci. USA 98, 10614-10619 (2001).

12. Plan, M. R., Saska, I., Cagauan, A. G. \& Craik, D. J. Backbone cyclised peptides from plants show molluscicidal activity against the rice pest Pomacea canaliculata (golden apple snail ). J. Agric. Food Chem. 56, 5237-5241 (2008).

13. Colgrave, M. L. et al. Cyclotides: natural, circular plant peptides that possess significant activity against gastrointestinal nematode parasites of sheep. Biochemistry 47, 5581-5589 (2008).

14. Colgrave, M. L. et al. Anthelmintic activity of cyclotides: In vitro studies with canine and human hookworms. Acta Trop. 109, 163-166 (2009).

15. Poth, A. G., Chan, L. Y. \& Craik, D. J. Cyclotides as grafting frameworks for protein engineering and drug design applications. Biopolymers 100, 480-491 (2013).

16. Clark, R. J. et al. Engineering stable peptide toxins by means of backbone cyclization: stabilization of the alpha-conotoxin MII. Proc. Natl Acad. Sci. USA 102, 2-7 (2005).

17. Clark, R. J. et al. The engineering of an orally active conotoxin for the treatment of neuropathic pain. Angew. Chem. Int. Ed. Engl. 49, 6545-6548 (2010).

18. Chan, L. Y. et al. Cyclization of the antimicrobial peptide gomesin with native chemical ligation: influences on stability and bioactivity. Chembiochem 14, 617-624 (2013).

19. Craik, D. J. Host-defense activities of cyclotides. Toxins (Basel) 4, 139-156 (2012).

20. Stanger, K. et al. Backbone cyclization of a recombinant cystine-knot peptide by engineered Sortase A. FEBS Lett. 588, 4487-4496 (2014).

21. Conlan, B. F. et al. Insights into processing and cyclization events associated with biosynthesis of the cyclic Peptide kalata B1. J. Biol. Chem. 287, 28037-28046 (2012).

22. Mylne, J. S. et al. Albumins and their processing machinery are hijacked for cyclic peptides in sunflower. Nat. Chem. Biol. 7, 257-259 (2011).

23. Hiraiwa, N., Nishimura, M. \& Hara-Nishimura, I. Expression and activation of the vacuolar processing enzyme in Saccharomyces cerevisiae. Plant J. 12, 819-829 (1997). 
24. Hiraiwa, N., Nishimura, M. \& Hara-Nishimura, I. Vacuolar processing enzyme is self-catalytically activated by sequential removal of the C-terminal and N-terminal propeptides. FEBS Lett. 447, 213-216 (1999).

25. Kuroyanagi, M. et al. Activation of Arabidopsis vacuolar processing enzyme by self-catalytic removal of an auto-inhibitory domain of the C-terminal propeptide. Plant Cell Physiol. 43, 143-151 (2002).

26. Kembhavi, A. A., Buttle, D. J., Knight, G. \& Barrett, A. J. The two cysteine endopeptidases of legume seeds: purification and characterization by use of specific flurometric assays. Arch. Biochem. Biophys. 303, 208-213 (1993).

27. Hatsugai, N. et al. A plant vacuolar protease, VPE, mediates virus-induced hypersensitive cell death. Science 305, 855-858 (2004).

28. Dall, E. \& Brandstetter, H. Mechanistic and structural studies on legumain explain its zymogenicity, distinct activation pathways, and regulation. Proc. Natl Acad. Sci. USA 110, 10940-10945 (2013).

29. Chen, J. et al. Cloning, Isolation, and Characterization of Mammalian Legumain, an Asparaginyl Endopeptidase. J. Biol. Chem. 272, 8090-8098 (1997).

30. Conlan, B. F. et al. Circular proteins and mechanisms of cyclization. Biopolymers 94, 573-583 (2010).

31. Dall, E., Fegg, J. C., Briza, P. \& Brandstetter, H. Structure and mechanism of an aspartimide-dependent peptide ligase in human legumain. Angew. Chem. Int. Ed. Engl. 54, 2917-2921 (2015).

32. Harris, K. S. et al. Binding hot spot for invasion inhibitory molecules on plasmodium falciparum apical membrane antigen 1. Infect. Immun. 73, 6981-6989 (2005).

33. Harris, K. S. et al. Rapid optimization of a peptide inhibitor of malaria parasite invasion by comprehensive $\mathrm{N}$-methyl scanning. J. Biol. Chem. 284, 9361-9371 (2009).

34. Abe, Y. et al. Asparaginyl Endopeptidase of Jack Bean Seeds. J. Biol. Chem. 268, 3525-3529 (1993).

35. Dall, E. \& Brandstetter, H. Activation of legumain involves proteolytic and conformational events, resulting in a context- and substrate-dependent activity profile. Acta Crystallogr. Sect. F. Struct. Biol. Cryst. Commun. 68, 24-31 (2012).

36. Chen, J. M., Dando, P. M., Stevens, R. A, Fortunato, M. \& Barrett, A J. Cloning and expression of mouse legumain, a lysosomal endopeptidase. Biochem. J. 335(Pt 1): 111-117 (1998)

37. McIntosh, J. A. et al. Circular logic: nonribosomal peptide-like macrocyclization with a ribosomal peptide catalyst. J. Am. Chem. Soc. 132, 15499-15501 (2010).

38. Koehnke, J., Bent, A., Houssen, W. E., Zollman, D. \& Morawitz, F. The mechanism of patellamide macrocyclization revealed by the characterization of the PatG macrocyclase domain. Nat. Struct. Mol. Biol. 19, 767-772 (2012).

39. Jung, R. et al. The role of proteolysis in the processing and assembly of $11 \mathrm{~S}$ seed globulins. Plant Cell 10, 343-357 (1998)

40. Simonsen, S. M., Daly, N. L. \& Craik, D. J. Capped acyclic permutants of the circular protein kalata B1. FEBS Lett. 577, 399-402 (2004).

41. Schulz, M. H., Zerbino, D. R., Vingron, M. \& Birney, E. Oases: robust de novo RNA-seq assembly across the dynamic range of expression levels. Bioinformatics 28, 1086-1092 (2012).

42. Li, W. \& Godzik, A. Cd-hit: a fast program for clustering and comparing large sets of protein or nucleotide sequences. Bioinformatics 22, 1658-1659 (2006).

43. Li, H. \& Durbin, R. Fast and accurate short read alignment with BurrowsWheeler transform. Bioinformatics 25, 1754-1760 (2009).
44. Qin, Q. et al. Identification of candidates for cyclotide biosynthesis and cyclisation by expressed sequence tag analysis of Oldenlandia affinis. BMC Genomics 11, 111 (2010).

45. Altschul, S., Gish, W., Miller, W., Myers, E. \& Lipman, D. Basic local alignment search tool. J. Mol. Biol. 215, 403-410 (1990).

46. Koressaar, T. \& Remm, M. Enhancements and modifications of primer design program Primer3. Bioinformatics 23, 1289-1291 (2007).

47. Catanzariti, A., Soboleva, T. A., Jans, D. A., Board, P. G. \& Baker, R. T. An efficient system for high-level expression and easy purification of authentic recombinant proteins. Protein Sci. 13, 1331-1339 (2004).

48. Liu, Y. et al. Use of a fluorescence plate reader for measuring kinetic parameters with inner filter effect correction. Anal. Biochem. 267, 331-335 (1999).

\section{Acknowledgements}

We thank Ms Rosemary Guarino for assistance with expressions, Dr Pedro Quimbar and Dr Thomas Shafee for helpful discussions, Mr Owen McCorkelle and Dr Suresh Mathivanan for preliminary MS analysis, Mr James Brown for isolation of the AEP sequence from genomic DNA, Professor Michael Foley for providing the native R1 peptide, Mr Alun Jones and the Institute for Molecular Bioscience Mass Spectrometry Facility for expertise and access to MS equipment and Dr Joshua Mylne for assistance with transcriptomics. This work was supported by The Australian Research Council grants DP0984390 and DP150100443 and Hexima Ltd.

\section{Author contributions}

K.S.H. produced the recombinant enzyme and carried out cyclization assays and kinetic analysis. T.D. and N.L.D. synthesized cyclotide precursors. T.D. carried out NMR and HPLC co-elution studies. T.D., Q.K., E.K.G. and I.S. contributed to the isolation of AEP sequences. T.D. and A.G.P. carried out mass spectrometry analysis of the recombinant AEP. B.F.C. produced rabbit antiserum. K.S.H., T.D., N.L.v.d.W., D.J.C. and M.A.A. contributed to study design and data analysis. All authors contributed to the writing and/or review of the manuscript.

\section{Additional information}

Supplementary Information accompanies this paper at http://www.nature.com/ naturecommunications

Competing financial interests: The authors declare no competing financial interests.

Reprints and permission information is available online at http://npg.nature.com/ reprintsandpermissions/

How to cite this article: Harris, K. S. et al. Efficient backbone cyclization of linear peptides by a recombinant asparaginyl endopeptidase. Nat. Commun. 6:10199 doi: 10.1038/ncomms10199 (2015).

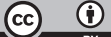

This work is licensed under a Creative Commons Attribution 4.0 International License. The images or other third party material in this article are included in the article's Creative Commons license, unless indicated otherwise in the credit line; if the material is not included under the Creative Commons license, users will need to obtain permission from the license holder to reproduce the material. To view a copy of this license, visit http://creativecommons.org/licenses/by/4.0/ 